\title{
Strength of Bank-Firm Nexus: Evidence from Islamic and Conventional Banks
}

\author{
Shahbaz Khan ${ }^{1 *}$ Nida Baig ${ }^{2}$, Shahzad Hussain ${ }^{3}$, Ajid Ur Rehman 4 \\ ${ }^{1}$ Faculty of Management Sciences, Foundation University Islamabad, Pakistan \\ ${ }^{2}$ College of Public Administration, Huazhong University of Science and Technology, Wuhan, China \\ ${ }^{3}$ Faculty of Management Sciences, Foundation University Islamabad, Pakistan \\ ${ }^{4}$ Faculty of Management Sciences, Riphah International University, Islamabad, Pakistan
}

\section{Keywords \\ Islamic Banks \\ Conventional Banks \\ Non-Financial Firms \\ Bank-Firm Relationship}

Received: 22 August 2019

Accepted: 14 March 2020

\begin{abstract}
This article discovers that whether there is a closer liaison between Islamic banks and non-financial firms, or conventional banks and non-financial firms, specifically in Muslim countries economies where dual banking systems exist. Based on a sample, drawn from a cross-section of OIC countries, the results of univariate analysis on our full sample shows that mean values of conventional bank-firm relationship variables are higher than the mean values of Islamic bank-firm relationship variables, suggesting the competitive edge of conventional banks over Islamic banks. However, the results of a sub-sample where fraction of Islamic banks operating in a country is larger than conventional banks provide evidence in favour of Islamic banks. As per the recent report of IMF, Islamic banks are growing at a considerable pace in Muslim countries, so it might be estimated that they contain a stronger potential to surpass their conventional counterparts while building and maintaining a closer nexus with the non-financial firms operating in these countries.
\end{abstract}

KAUJIE Classification: L25, L26

JEL Classification: C31, G21, G30, Z12

(c) 2020 JIBM. All rights reserved.

\section{INTRODUCTION}

Religious values tend to influence an individual's beliefs, attitude, living style, traditions and even financing decisions (Mobin \& Masih, 2014; Renneboog \& Spaenjers, 2012). If the religious values give rise to different financial decisions across different regions then we can hypothesize that individuals residing in Islamic countries may think about banking in a

\footnotetext{
* Corresponding author: Shahbaz Khan

†Email: shahbaz.khans@yahoo.com
} 
different way (Kumru \& Sarntisart, 2016). Firms are run by individuals so, their nature is likely to influence firms' financing decisions (Hilary \& Hui, 2009).

Mark up or Interest rate impacts all economic bodies but its effect is major on banking sector. From a banker's perspective, interest rate is the money that borrower gives or lender gets in excess of actual money (Marshall, 1923). But Islam does not allow ribā or usury (namely, interest) in any of financial dealings. "Ribā" is an Arabic word which means an excess or in addition to actual amount of loan, debt or credit (Saeed, 1996). As in Holy Quran Allah distinctly narrates:

"O you who believe! Be mindful of God and give up what remains of al-riba if you are believers. If you do not do so, then receive a declaration of war from God and his Messenger. But if you repent, you shall have your capital sums. You do not deal unjustly and you are not dealt with unjustly (2:278-279)". Prophet Muhammad (PBUH) in his last address eradicated this immoral rent seeking on money (interest) and knocked it out from society, Prophet further said that:

"All interest and usurious dues accruing from the times of ignorance stand wiped out. And the first amount of Interest that I remit is that which Abbas ibn Abd-al Muttalib had to receive. Verily, it is remitted entirely."

It is literally well documented that conventional borrowing involves the interest, which is against the religious thesis of Muslims, while taking a borrowing decision. The researchbacked notable associated reasons may comprise of: firstly, he has a trust on religious institutions; secondly, his conscience can prick him; and finally, he is living in a religious society that might cause him to face inhabitants' critics.

Empirical literature review supports that religious values influence the investment, financing and asset management decisions of individuals and corporations as well (Hilary \& Hui, 2009; Mushtaq \& Siddiqui, 2016, 2017; Renneboog \& Spaenjers, 2012). Given this noticeable influence, it seems quite important for non-financial firms to choose between an Islamic-or a conventional bank as their close financial partner. Accordingly, we are encouraged to do a comparison between strength of Islamic bank-firm ties versus conventional bank-firm relationship to check out whether a stronger bond exists between Islamic banks and non-financial firms or conventional banks and non-financial firms in our sample countries?

This article is different from the earlier work on the comparison between Islamic and conventional banks in that: (1) all the well-established literature is focused on comparing the performance, efficiency, and risk based measures between the above mentioned two forms of banking (Abdul-Majid, Saal, \& Battisti, 2010; Ariss, 2010; Bader, Mohamad, Ariff, \& Hassan, 2008; Beck, Ongena, \& Sendeniz-Yuncu, 2013; Johnes, Izzeldin, \& Pappas, 2014; Kabir, Worthington, \& Gupta, 2015; Khediri, Charfeddine, \& Youssef, 2015; Srairi, 2010), while within the context of relationship banking, the discussion on the comparison between these two types of banks is rare; (2) as per our best of knowledge, none of the study attempted to investigate a broader and more representative dataset of Organization of Islamic conference (hereinafter referred to as OIC) countries. The economies of OIC member states provide us a good backup as out of the total of 176 Islamic banks, 166 are working in OIC countries ("Orbis Bank Focus,"). So, this article is an attempt to fill this void in the literature. 
In order to find out the difference between two set of groups, we perform univariate analysis (t-test of means) in order to test our main hypothesis. The results of the full sample used in this study show that mean values of conventional bank-firm relationship variables are higher than the mean values of Islamic bank-firm relationship variables, suggesting the competitive edge of conventional banks over Islamic banks. However, results of a sub-sample where fraction of Islamic banks operating in a country is larger than conventional banks (please see table 5) provide evidence in favour of Islamic banks. So, Islamic banks may have a comparative advantage over conventional banks in the context of bank-firm relationship if they contain a larger fraction of total Islamic banks operating in a country.

The rest of the paper is organized as follows: section 2 discusses a detailed literature review to construct some concrete hypotheses; next in section 3 , we run univariate analysis on our data; section 4 discusses the economic and statistical significance of the results; and finally section 5 summarizes and concludes the overall research in light of its practical and theoretical implications, its limitations and, scope for future research.

\section{LITERATURE REVIEW}

Beck, Ongena, and Sendeniz-Yuncu (2016) contended that, Islamic banks rely more on building close relationships with their non-financial firms. The Islamic participatory schemes integrate the assets of financiers and fund users, so allow Islamic banks to provide financing on a longer term basis to create projects with higher risk-return profiles (Daly \& Frikha, 2016). So, the efficient financing process of Islamic banks is likely to increase the efficiency of financial intermediation, and hence help firms to better access the finance. Also, Islamic banks are exposed towards a reduced systemic risk than conventional counterparts for their characteristics like risk-sharing and prohibition from speculation (IMF Annual Report, 2015). Thereby, such approach of Islamic banks can attract non-financial firms towards themselves as they realize that close relationship and efficient financing process may increase their probability of credit financing. This perception, no doubt, seems crucial in the sense that Islamic banks are less in percentage than conventional banks; then how it is possible for them to build comparatively stronger relationships than conventional banks. However, we may build our argument on the basis that the finance seekers of Muslim countries may be unwilling to go for conventional banking due to the involvement of interest bearing financing, so in that case, even the higher percentage of conventional banks might play a negligible role to attract potential borrowers in Muslim countries (Mohieldin, Iqbal, Rostom, \& Fu, 2012). The proximity, for example, is an important determinant to build a close relationship but, Beck et al. (2016) mentioned that, in Turkey it plays a muted role because firms prefer to choose Islamic banks even if an Islamic bank is located far away than a conventional bank.

Well established literature in the domain of relationship banking provides various indicators to measure strength of bank-firm liaison., such as, concentration of borrowing, as documented by (Petersen \& Rajan, 1994), can be one significant gauge to measure the closeness of bank-firm relationship. In another study, Machauer and Weber (2000) documented that a non-financial firm may secure its access to a higher fraction of credit from a bank with 
which it is in a close tie. As mentioned earlier in introduction part that there is a stronger influence of Islamic values or laws in Muslim countries, so these are more likely to influence a non-financial firm's decision to build a close tie with either an Islamic and/or Conventional bank.

In fact, the involvement of religious values creates some fundamental differences between Islamic finance and conventional finance. Following these established regulations by Islam, Sharia-compliant organizations are not permitted to charge interest cost (known as "rib $\bar{a} "$ ) on the on the amount of loan, debt or credit, and not allowed to involve in speculative contracts (Zaher \& Hassan, 2001) and all investments in illegal businesses (e.g., business of vine is considered as illegal). Critically, here interest $(r i b \bar{a})$ is the main determinant that may draw a distinction line between Islamic and conventional banking. We can also see some evidence in the literature on this point. Kassim, Majid, and Shabri, (2009), for example, checked the financial stability of Islamic and Conventional banks in Malaysia and, found Islamic banks to be more financially stable than their conventional counterparts as they had minimum exposure towards interest rate risk. Similarly, Tariq, and Masih (2016) could not find any significant effect of interest rate on Islamic bank deposits.

Islamic banking is working under Shariah principles, so clients with healthy religious minds might tend to be inclined more towards Islamic banking. And, in a country where Islam is a dominant religion, and also it is characterized by a dual banking âĂŞ Islamic and commercial banks are working side by side, the non-financial firms having religious preferences may prefer to go for Islamic banking; while the rest may opt to choose among either Islamic or/and conventional banks. Religious values also influence the risk attitudes of people. The already established debate depicted that, the more an individual is of religious mind, the higher he would be risk averse (e.g., see studies by Dyreng, Mayew, \& Williams, 2012; Hilary \& Hui, 2009; Miller \& Hoffmann, 1995). So, religiosity is likely to affect the bank's asset -as well as liability side by fulfilling the depositors and finance seekers demands under Islamic conditions.

Concisely, by keeping all other factors constant, we can base our thinking that religious factors would be more likely to affect the strength of relationship banking, specifically in Islamic countries where we can find highly concentrated religious minds individuals. Abedifar, Molyneux, and Tarazi, (2013) stated that at least 1/3rd of North American Muslims refused conventional mortgages, and were willing to pay more for religiously sound products. Furthermore, Nenova, Niang, and Ahmad (2009) reported that 1/5th of the Pakistani population was ready to devote more in order to avail Islamic financial products and services.

On the base of above arguments and discussion, we may hypothesize that:

H1: Islamic Banks would have stronger ties with non-financial firms in Muslim countries where dual banking system exists than their conventional counterparts.

\section{RESEARCH DESIGN}

\section{Data and Sample Description}

Based on a sample of non-financial firms and banks (both Islamic and conventional) from 16 OIC member states including Pakistan, Bangladesh, Malaysia, Turkey, Nigeria, Qatar, 
Bahrain, Kuwait, Saudi Arabia, Egypt, Iraq, Oman, Indonesia, Jordan, Tunisia, and United Arab Emirates as displayed in table 6 in appendix, we attempt to check whether Islamic banks, or conventional banks tend to maintain stronger ties with non-financial firms.

To collect data for bank-specific measures of both Islamic and conventional banks, we used ORBIS Bank Focus by Bureau van Dijk Electronic Publishing (hereinafter abbreviated as BVD). The banks (either Islamic or/and conventional) for which the data is missing have been excluded from the sample. First, we classified bank's orientation as Islamic or conventional. A bank is said to be Islamic "if it is in accordance with the philosophy and value structure of Islam and is governed by Shariah principles" (SBP) . Conversely, if a bank's products and services don't comply with Shariah-Law, it may be termed as a conventional bank (SBP). Regardless of their definitions, we relied on Bankscope by BVD to accumulate a complete list of Islamic and conventional banks operating in our sample countries. As compared to 568 conventional banks, Islamic banks are only 166, mostly working in MENA region (Orbis Bank Focus by BVD). The two big limitations of our data are: (1) it doesn't contain information on deposits given and financing taken by individuals or with an individual banking partner; (2) data on bank's shareholdings in non-financial firms is available for only one year, so it is cross-sectional in nature.

\section{Measurements of Dependent-and Independent Variables}

The relationship between firms and banks has been measured widely in literature in terms of the duration of the relationship, the scope of services, the concentration of borrowing (concentration), the degree of participation in the relationship (participation) (e.g., studies by Binks \& Ennew, 1996; Degryse \& Van Cayseele, 2000; Petersen \& Rajan, 1994); and equity holdings by banks (e.g., studies by Barucci \& Mattesini, 2008; Dass \& Massa, 2011; Limpaphayom \& Polwitoon, 2004; Lin, Zhang, \& Zhu, 2009; Luo \& Hachiya, 2005; Mahrt-Smith, 2006; Miarka \& Troge, 2005), who described bank's fraction of equity holding as the powerful tool to determine bank-firm relationship as it allows them to hold voting rights. Although an individual bank is allowed to hold a certain proportion of equity in most of the countries, but a coalition of banks would contain a largest percentage of shares, so could enable them to influence their decisions on a particular firm (Miarka \& Troge, 2005). Similarly, Mahrt-Smith (2006) mentioned bank's equity holding as a power tool to extract rents from firms, and even a minor fraction of bank's shareholdings is enough to exercise their monitoring control. We have cross-sectional data available on equity holding of banks in non-financial firms, so as per the availability of data, we used equity holding by banks in non-financial firms to measure bank-firm relationship.

The variables description is given in Table 1. To compare the strength of relationship between Islamic and conventional banks, we have used 'RB' as our dependent variable. 'RB' represents the overall bank-firm relationship and, is defined as "total fraction of equity holding by both Islamic and conventional banks in a non-financial firm i". It indicates the overall monitoring power of both conventional and Islamic banks. 
TABLE 1

Description of Variables

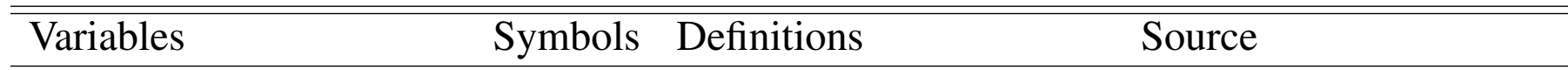

\section{Dependent Variables:}

Overall Bank-Firm Rela- RBi tionship

\section{Independent Variables:}

Islamic bank-firm rela- RBI tionship

Conventional bank-firm RBC relationship

Islamic Bank-firm Re- ARBI lationship (Alternate Proxy)

Conventional Bank-Firm Relationship (Alternate Proxy)

Close Relationship Be- CRI tween Islamic banks and a non-financial firm $\mathrm{i}$

Close Relationship be- CRC tween conventional banks and a non-financial firm i
Equity Holding by both Conventional and Islamic Banks in a non-financial firm ' $i$ '.

Fraction of equity holdings by Islamic banks in a non-financial firm ' $i$ '

\section{Fraction of equity hold-} ings by conventional banks in a non-financial firm 'i'

Equity Holding by Islamic Banks divided by total number of Islamic banks having equitybased relationship with that non-financial firm ' $i$ '.

ARBC Equity Holding by Conventional Banks divided by total number of conventional banks having equity-based relationships with that non-financial firm ' $i$ '.

A dummy variable that contains a value $=1$ if Islamic banks equity holding portion is greater than conventional bank's equity holdings; otherwise $=0$

A dummy variable that contains a value $=1$ if conventional banks equity holding portion is greater than Islamic bank's equity holdings; else $=0$
Hand collected from OSIRIS Bureau van Dijk Bureau van Dijk OSIRIS Bureau van Dijk OSIRIS Bureau van Dijk OSIRIS and ORBIS Bank Focus Bureau van Dijk OSIRIS and ORBIS Bank Focus

Author's Own Computation

Author's Own Computation 
RBI, RBC, ARBI, ARBC are main variables of interest for our model. Where, RBI represents the "fraction of equity holdings by Islamic banks in a non-financial firm ' $i$ '; RBC represents the "percentage of equity ownership by conventional banks in a non-financial firm ' $i$ '; ARBI is an alternate measure to gauge Islamic bank-firm relationship which is calculated as "equity Holding by Islamic Banks divided by total number of Islamic banks having equity-based relationships with that non-financial firm ' $i$ '"; ARBC is also defined in a similar way i.e., "equity holding by conventional banks divided by total number of conventional banks having equity-based relationships with that non-financial firm 'i', CRI represents stronger bond among Islamic banks and, a non-financial firm ' $\mathrm{i}$ ' which is measured by a dummy variable that takes the value $=1$, if Islamic banks contain a larger portion of equity than conventional banks; otherwise $=0$, and finally $\mathrm{CRC}$ denotes closer association between conventional banks and a non-financial firm ' $i$ ' which is defined by another dummy that is equal to 1 , if conventional banks hold a higher percentage of shares than Islamic banks; else $=0$.

Analytically, (1) if mean value of $\mathrm{RBI}>$ mean value $\mathrm{RBC}$, we may suggest that there exists a stronger liaison between Islamic banks and non-financial firms; thereby, our main hypothesis (H1) would come true; (2) conversely, if mean value of $\mathrm{RBC}>$ mean value of RBI, then H1 would not be accepted; so, we may infer that there exists a stronger association between conventional banks and non-financial firms. If our prior case comes true, then we might suggest that Islamic banks have a competitive advantage over conventional banks in establishing a close relationship with non-financial firms, specifically in Muslim countries where dual banking system exists.

Fraction of total number of Islamic or/and conventional banks operating in a country could bias our results, as Islamic banking industry is still in its growing stage and, number of Islamic banks is less than that of conventional banks in most of the countries in our sample. Therefore, it is important to notice that whether the stronger relationship is affected by its total percentage of banks operating in a country. We try to reduce this sample bias by generating two additional sub-samples: one with countries having more number of conventional banks than Islamic banks; and other with countries containing more number of Islamic banks than conventional banks.

\section{Analysis Technique}

To attain our main objective i.e., to examine whether Islamic bank-firm, or conventional bank-firm relationship is stronger in Muslim countries, we first show our preliminary findings by descriptive statistics as shown in table 2 , and then further confirm these by performing univariate analysis among different Islamic bank-firm and conventional bank-firm relationship variables as shown in Tables $3,4 \& 5$.

\section{EMPIRICAL RESULTS AND DISCUSSION}

\section{Descriptive Statistics}

Table 2 displays the results for summary statistics of variables used in this study. We could notice that equity holding by all banks in non-financial firms as represented by RB contains 
the values from 0 to $99 \%$. Surprisingly, the banks might be holding approximately all shares in some firms which depict that there are no restrictions on banks to hold shares in non-financial for one/more countries in our sample. It is visible from descriptive statistics that CRC (close-relationship between conventional banks and firms) contain the higher mean value than CRI (close-relationship between Islamic banks and firms). We observe similar findings during our univariate analysis as displayed in Table 3.

TABLE 2

Descriptive Statistics

\begin{tabular}{llllll}
\hline \hline Variable & Obs & Mean & S.D & Min. & Max. \\
\hline RB & 3228 & 3.37 & 10.13 & 0.00 & 99.00 \\
ARB & 3228 & 2.00 & 7.31 & 0.00 & 99.00 \\
CRI & 3228 & 0.10 & 0.30 & 0.00 & 1.00 \\
CRC & 3228 & 0.14 & 0.35 & 0.00 & 1.00 \\
\hline \hline
\end{tabular}

\section{Univariate Analysis}

According to the essence of our hypothesis, our analysis involves comparing the mean differences between two set of groups (Ho, 2006) i.e., Islamic bank-firm relationships versus conventional bank-firm relationships. So, we opted for the univariate comparison including t-test of means (Zumbo, 2014). In table 3, we reported the univariate analysis for our full sample. We can notice that the mean value of RBC (conventional bank-firm relationship proxy) is 1.49 which is greater than the mean value of RBI (Islamic bank-firm relationship proxy) i.e., 0.96 , clearly indicating the existence of stronger relationship between conventional banks and non-financial firms than between Islamic banks and non-financial firms, which is further confirmed by comparatively less mean values of alternate proxies ARBI and CRI (Islamic bank-firm relationship indicators) than ARBC and CRC ( conventional bank-firm relationship indicators).

These findings refer to the rejection of our first hypothesis, but we don't yield a final conclusion, as we notice that the total number of conventional banks is far more than number of Islamic banks in our sample, which may bias our results. To avoid such biasness and further dig out this phenomenon, we consider the total number of banks operating in a country as well. To do so, we conduct two more univariate comparisons on our data: (1) one with a sub-sample containing more number of conventional banks than Islamic banks including a total of 12 countries; (2) the other with a sub-sample having more number of Islamic banks than conventional ones containing a total of 4 countries. We find results in favour of conventional banks for the prior sample as depicted in table 4 and, for the later one, Islamic banks surpassed the Islamic counterparts as shown in table 5. Thereby, it seems viable to suggest that religious values alone cannot lead a bank towards the establishment of a stronger bank-firm relationship, while total numbers of available financial options also affect the firm's choice to select its banking partner, ceteris paribus. 


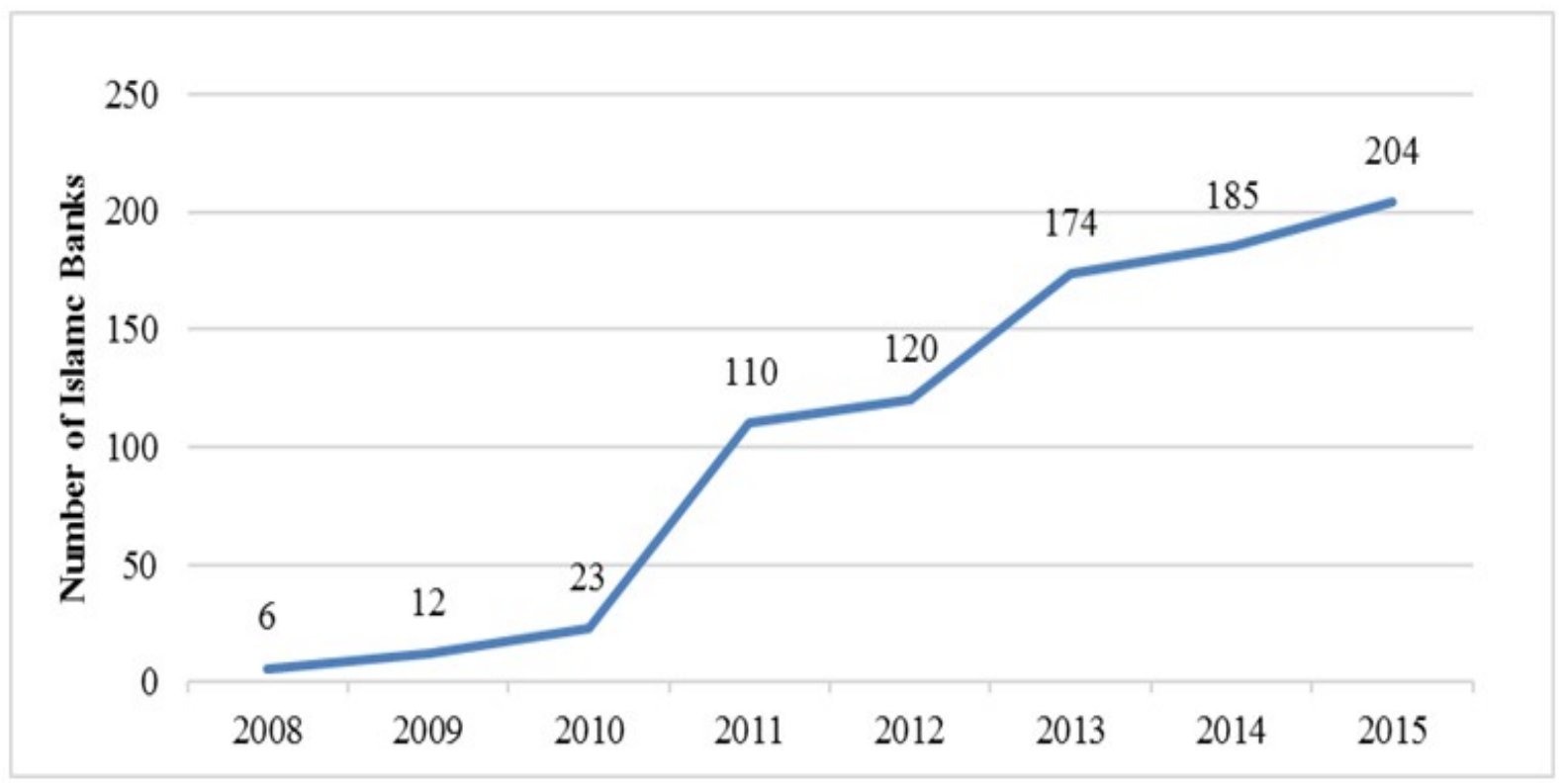

FIGURE 1. Figure 1. Growth in Number of Islamic Banks during 2008-2015

Source: BvDOrbis Bank Focus

TABLE 3

Univariate Analysis to Determine Strength of Bank-Firm Relationship between Islamic -and Conventional Banks for Full Sample (Paired t-test)

\begin{tabular}{llll}
\hline \hline Variables & Mean & Difference & $t$-statistics \\
\hline RBI & 0.96 & & \\
RBC & 1.49 & -0.52 & -3.38 \\
ARBI & 0.86 & & \\
ARBC & 1.22 & -0.36 & -2.51 \\
CRI & 0.09 & & \\
CRC & 0.14 & -0.04 & -5.05 \\
\hline \hline
\end{tabular}

TABLE 4

Univariate Analysis to Compare Strength of Bank-Firm Relationship among Islamic -and Conventional Banks for a Sub-sample

\begin{tabular}{llll}
\hline \hline Variables & Mean & Difference & $t$-statistics \\
\hline RBI & 0.80 & & \\
RBC & 1.40 & -0.60 & -3.94 \\
ARBI & 0.72 & & \\
ARBC & 1.14 & -0.36 & -3.01 \\
CRI & 0.09 & & \\
CRC & 0.14 & -0.04 & -5.46 \\
\hline \hline
\end{tabular}

Notes that from Table 3: $t$-statistics value determines the significance of the mean difference between RBI and RBC, $\mathrm{ARBI}$ and $\mathrm{ARBC}$, and CRI and CRC. RBI refers to Islamic 
Bank-Firm relationship which is defined as "equity holding by Islamic banks in a nonfinancial firm i". RBC denotes conventional bank-firm relationship that is measured asâĂ equity holding by conventional banks in a non-financial firm i". ARBI refers to average ratio of Islamic bank-firm relationship that is gauged as "equity holding by Islamic banks divided by total number of Islamic banks". ARBC refers to average ratio of conventional bank-firm relationship that is measured as "equity holding by conventional banks divided by total number of conventional banks". CRI indicates close relationship of Islamic banks that is defined by a dummy variable which is equal to 1 if Islamic banks hold larger part of equity than conventional banks; else $=0 "$. CRC denotes close relationship of conventional banks which is also measured by a dummy that takes the value $=1$ if conventional banks hold a larger portion of equity than Islamic banks; otherwise $=0$ '.

Similarly, from Table: $t$-statistics value determines the significance of the mean difference between RBI and RBC, ARBI and ARBC, and CRI and CRC. RBI refers to Islamic BankFirm relationship which is defined as "equity holding by Islamic banks in a non-financial firm i". RBC denotes conventional bank-firm relationship that is measured as;

TABLE 5

Univariate Analysis to Compare Strength of Bank-Firm Relationship among Islamic -and Conventional Banks for a Sub-sample

\begin{tabular}{llll}
\hline \hline Variables & Mean & Difference & t-statistics \\
RBI & 3.30 & & \\
RBC & 2.75 & 0.54 & 0.56 \\
ARBI & 2.99 & & \\
ARBC & 0.50 & 0.49 & 0.52 \\
CRI & 0.16 & & \\
CRC & 0.14 & 0.02 & 0.62 \\
\hline
\end{tabular}

From Table 5, $t$-statistics value determines the significance of the mean difference between $\mathrm{RBI}$ and $\mathrm{RBC}, \mathrm{ARBI}$ and $\mathrm{ARBC}$, and CRI and CRC. RBI refers to Islamic Bank-Firm relationship which is defined as "equity holding by Islamic banks in a non-financial firm i". $\mathrm{RBC}$ denotes conventional bank-firm relationship that is measured as" equity holding by conventional banks in a non-financial firm i".

\section{CONCLUSION}

An extensive body of literature compares the performance, efficiency, and risk based variables between Islamic and conventional banks (Abdul-Majid et al., 2010; Ariss, 2010; Bader et al., 2008; Beck et al., 2013; Johnes et al., 2014; Kabir et al., 2015; Khediri et al., 2015; Srairi, 2010). However, we can find a rare discussion on the comparison between these two types of banks within the context of relationship banking. As per our best of knowledge, none of the study attempted to investigate whether there exists a stronger bond between Islamic banks and non-financial firms or conventional banks and non-financial firms, specifically in Muslim countries where there exists a dual banking system. So, it is timely and necessary to 
crack out this domain for extending the bank-firm relationship literature. As per the nature of our hypothesis, we needed to compare the mean differences between two set of groups i.e., between Islamic bank-firm nexus and conventional bank-firm nexus. So, we performed univariate analysis (t-test of means) to check whether the mean values of Islamic bank-firm relationship proxies are greater than the mean values of conventional bank-firm relationship indicators.

The results of our full sample show that competitive power of Islamic bank-firm relationships is less than conventional bank-firm relationships, which is in line with what Ariss (2010) and Weill (2011) evidenced regarding less competitive power of Islamic banks than conventional ones. The results of a sub-sample where number of Islamic banks operating in a country is larger than conventional banks provide evidence in support of our hypothesis. So, Islamic banks may have a comparative advantage over conventional banks in context of bank-firm relationship, if they contain a larger fraction of total Islamic banks operating in a country. Ceteris paribus, it seems viable to suggest that religious beliefs alone cannot lead a bank towards the establishment of a stronger bank-firm relationship, while the total numbers of available financial options also affect the firm's choice to select its banking partner. However, Islamic banking is growing enormously after the global financial crises 2008 (as in figure 1, IMF, 2019), so we might expect more close relationships between Islamic banks and non-financial firms than conventional banks in future, specifically in Muslim countries where dual banking system exists.

The study has several caveats which are mandatory to disclose in order to guide academicians for further contribution in this domain. Firstly, we have to rely only on one facet of bank-firm relationship i.e., bank-firm equity relationships as per the availability of data. However, relationship in banking is far beyond this and can also be defined in terms of bank-firm deposit âĂŞand bank-firm credit relationships. So, further studies should include other indicators of relationship banking as well in order to present more defined, elaborative, and generalized findings. Secondly, our sample is cross-sectional in nature while more heterogeneous and dynamic results are expected in Panel data.

\section{REFERENCES}

Abdul-Majid, M., Saal, D. S., \& Battisti, G. (2010). Efficiency in Islamic and conventional banking: an international comparison. Journal of Productivity Analysis, 34(1), 25-43. doi: https://doi.org/10.1007/s11123-009-0165-3

Abedifar, P., Molyneux, P., \& Tarazi, A. (2013). Risk in Islamic banking. Review of Finance, 17(6), 2035-2096. doi: https://doi.org/10.1093/rof/rfs041

Ariss, R. T. (2010). Competitive conditions in Islamic and conventional banking: A global perspective. Review of Financial Economics, 19(3), 101-108.

doi: https://doi.org/10.1016/j.rfe.2010.03.002

Bader, M. K. I., Mohamad, S., Ariff, M., \& Hassan, T. (2008). Cost, revenue and profit efficiency of Islamic versus conventional banks: International evidence using data envelopment analysis. Islamic Economic Studies, 15(2), 23-76.

Barucci, E., \& Mattesini, F. (2008). Bank shareholding and lending: Complementarity or 
substitution? Some evidence from a panel of large Italian firms. Journal of Banking $\mathcal{E}$ Finance, 32(10), 2237-2247. doi: https://doi.org/10.1016/j.jbankfin.2007.12.045

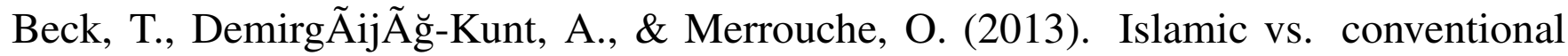
banking: Business model, efficiency and stability. Journal of Banking $\mathcal{E}$ Finance, 37(2), 433-447. doi: https://doi.org/10.1016/j.jbankfin.2012.09.016

Beck, T., Ongena, S., \& Åđendeniz-YÃijncÃij, Äř. (2019). Keep walking? Geographical proximity, religion, and relationship banking. Journal of Corporate Finance, 55, 49-68. doi: https://doi.org/10.1016/j.jcorpfin.2018.07.005

Binks, M. R., \& Ennew, C. T. (1996). Growing firms and the credit constraint. Small Business Economics, 8(1), 17-25. doi: https://doi.org/10.1007/BF00391972

Chen, Z., Li, Y., \& Zhang, J. (2016). The bankâĂŞfirm relationship: Helping or grabbing? International Review of Economics $\mathcal{F}$ Finance, 42, 385-403.

doi: https://doi.org/10.1016/j.iref.2015.10.010

Daly, S., \& Frikha, M. (2016). Banks and economic growth in developing countries: What about Islamic banks? Cogent Economics $\mathcal{E}$ Finance, 4(1), 1168728.

doi: https://doi.org/10.1080/23322039.2016.1168728

Dass, N., \& Massa, M. (2011). The impact of a strong bank-firm relationship on the borrowing firm. The Review of Financial Studies, 24(4), 1204-1260. doi: https://doi.org/10.1093/rfs/hhp074

Degryse, H., \& Van Cayseele, P. (2000). Relationship lending within a bank-based system: Evidence from European small business data. Journal of Financial intermediation, 9(1), 90-109. doi: https://doi.org/10.1006/jfin.1999.0278

Dyreng, S. D., Mayew, W. J., \& Williams, C. D. (2012). Religious Social Norms and Corporate Financial Reporting. Journal of Business Finance $\mathcal{E}$ Accounting, 39(7-8), 845-875. doi: https://doi.org/10.1111/j.1468-5957.2012.02295.x

Hilary, G., \& Hui, K. W. (2009). Does religion matter in corporate decision making in America? Journal of Financial Economics, 93(3), 455-473.

doi: https://doi.org/10.1016/j.jfineco.2008.10.001

Ho, R. (2006). Handbook of univariate and multivariate data analysis and interpretation with SPSS. Chapman and Hall/CRC. doi: https://doi.org/10.1201/9781420011111

IMF Annual Report. (2015). Appendix II-Financial operations and transactions. Retrieved from: https://rb.gy/nflmzl

IMF Annual Report. (2019). Part 2: What we do. Retrieved from: https://rb.gy/n9yjpv1

Johnes, J., Izzeldin, M., \& Pappas, V. (2014). A comparison of performance of Islamic and conventional banks 2004âĂŞ2009. Journal of Economic Behavior $\mathcal{E}$ Organization, 103, S93-S107. doi: https://doi.org/10.1016/j.jebo.2013.07.016

Kabir, M. N., Worthington, A., \& Gupta, R. (2015). Comparative credit risk in Islamic and conventional bank. Pacific-Basin Finance Journal, 34, 327-353.

doi: https://doi.org/10.1016/j.pacfin.2015.06.001

Kassim, S., Majid, A., \& Shabri, M. (2009). Impact of monetary policy shocks on the conventional and Islamic banks in a dual banking system: Evidence from Malaysia. Journal of Economic Cooperation and Development, 30(1), 41-58. 
Khediri, K. B., Charfeddine, L., \& Youssef, S. B. (2015). Islamic versus conventional banks in the GCC countries: A comparative study using classification techniques. Research in International Business and Finance, 33, 75-98. doi: https://doi.org/10.1016/j.ribaf.2014.07.002

Kumru, C. S., \& Sarntisart, S. (2016). Banking for those unwilling to bank: Implications of Islamic banking systems. Economic Modelling, 54, 1-12.

doi: https://doi.org/10.1016/j.econmod.2015.12.011

Limpaphayom, P., \& Polwitoon, S. (2004). Bank relationship and firm performance: evidence from Thailand before the Asian financial crisis. Journal of Business Finance $\mathcal{F}$ Accounting, 31(9âĂ ̌̌10), 1577-1600. doi: https://doi.org/10.1111/j.0306686X.2004.00585.X

Lin, X., Zhang, Y., \& Zhu, N. (2009). Does bank ownership increase firm value? Evidence from China. Journal of International Money and Finance, 28(4), 720-737. doi: https://doi.org/10.1016/j.jimonfin.2008.12.015

Luo, Q., \& Hachiya, T. (2005). Corporate governance, cash holdings, and firm value: evidence from Japan. Review of Pacific Basin Financial Markets and Policies, 8(4), 613-636. doi: https://doi.org/10.1142/S0219091505000580

Machauer, A., \& Weber, M. (2000). Number of bank relationships: An indicator of competition, borrower quality, or just size (Working Paper No: 2000/06). Center for Financial Studies (CFS), Goethe University Frankfurt, Frankfurt, Germany.

Mahrt-Smith, J. (2006). Should banks own equity stakes in their borrowers? A contractual solution to hold-up problems. Journal of Banking \& Finance, 30(10), 2911-2929. doi: https://doi.org/10.1016/j.jbankfin.2005.12.003

Marshall, A. (1923). Money, credit E commerce. London, UK: Macmillan Inc.

Miarka, T., \& Troge, M. (2005). Do bank-firm relationships reduce bank debt? Evidence from Japan. The European Journal of Finance, 11(1), 75-92.

doi: https://doi.org/10.1080/1351847032000168687

Miller, A. S., \& Hoffmann, J. P. (1995). Risk and religion: An explanation of gender differences in religiosity. Journal for the Scientific Study of Religion, 34(1), 63âĂŞ75. doi: https://doi.org/10.2307/1386523

Mobin, M. A., \& Masih, M. (2014). Do the macroeconomic variables have any impact on the Islamic bank deposits? An application of ARDL approach to the Malaysian market (MPRA Paper No. 62342). Munich Personal RePEc Archive (MPRA), Munich University Library, Munich, Germany.

Mohieldin, M., Iqbal, Z., Rostom, A., \& Fu, X. (2012). The role of Islamic finance in enhancing financial inclusion in Organization of Islamic Cooperation (OIC) countries. Islamic Economic Studies, 20(2), 55-120. doi: https://doi.org/10.1596/1813-9450-5920

Mushtaq, S., \& Siddiqui, D. A. (2016). Effect of interest rate on economic performance: evidence from Islamic and non-Islamic economies. Financial Innovation, 2(1), 9. doi: https://doi.org/10.1186/s40854-016-0028-7

Mushtaq, S., \& Siddiqui, D. A. (2017). Effect of interest rate on bank deposits: Evidences from Islamic and non-Islamic economies. Future Business Journal, 3(1), 1-8. doi: https://doi.org/10.1016/j.fbj.2017.01.002 
Nenova, T., Niang, C. T., \& Ahmad, A. (2009). Bringing finance to Pakistan's poor: Access to finance for small enterprises and the underserved. Washington, D.C., US: World Bank Publications. doi: https://doi.org/10.1596/978-0-8213-8030-7

Petersen, M. A., \& Rajan, R. G. (1994). The benefits of lending relationships: Evidence from small business data. The Journal of Finance, 49(1), 3-37.

doi: https://doi.org/10.1111/j.1540-6261.1994.tb04418.x

Renneboog, L., \& Spaenjers, C. (2012). Religion, economic attitudes, and household finance. Oxford Economic Papers, 64(1), 103-127. doi: https://doi.org/10.1093/oep/gpr025

Saeed, A. (1996). Islamic banking and interest: A study of the prohibition of ribā and its contemporary interpretation (Vol. 2). Leiden, Netherlands: Brill Publishers.

Srairi, S. A. (2010). Cost and profit efficiency of conventional and Islamic banks in GCC countries. Journal of Productivity Analysis, 34(1), 45-62.

doi: https://doi.org/10.1007/s11123-009-0161-7

Tariq, A., \& Masih, M. (2016). Risk-sharing deposits in islamic banks: Do interest rates have any influence on them (MPRA Paper No. 71680)? Munich Personal RePEc Archive (MPRA), Munich University Library, Munich, Germany.

Weill, L. (2011). Do Islamic banks have greater market power? Comparative Economic Studies, 53(2), 291-306. doi: https://doi.org/10.1057/ces.2011.1

Zaher, T. S., \& Kabir Hassan, M. (2001). A comparative literature survey of Islamic finance and banking. Financial Markets, Institutions $\mathcal{E}$ Instruments, 10(4), 155-199. doi: https://doi.org/10.1111/1468-0416.00044

Zumbo B. D. (2014) Univariate tests. In A. C. Michalos (Ed.), Encyclopedia of quality of life and well-being research. Dordrecht, Netherlands: Springer.

doi: https://doi.org/10.1007/978-94-007-0753-5_3110

$* * * * * * * * * * * * * * *$

TABLE 6

Overview of the Sample

\begin{tabular}{|c|c|c|c|c|c|}
\hline Sr. No. & Country & No. of Islamic Banks & No. of Conventional Banks & Restrictions to Hold Equity & No. of Non-Financial Firms \\
\hline 1 & Bahrain & 21 & 9 & 1 & 21 \\
\hline 2 & Bangladesh & 9 & 41 & 3 & 162 \\
\hline 3 & Egypt & 15 & 23 & 3 & 211 \\
\hline 4 & Indonesia & 11 & 64 & 3.5 & 429 \\
\hline 5 & Iraq & 7 & 10 & 3.5 & 44 \\
\hline 6 & Jordan & 3 & 11 & 3 & 184 \\
\hline 7 & Kuwait & 11 & 6 & 2 & 157 \\
\hline 8 & Malaysia & 19 & 32 & 3 & 841 \\
\hline 9 & Nigeria & 1 & 19 & 3 & 104 \\
\hline 10 & Oman & 3 & 6 & 3 & 108 \\
\hline 11 & Pakistan & 22 & 13 & 3 & 357 \\
\hline 12 & Qatar & 6 & 7 & 3 & 29 \\
\hline 13 & Saudi Arabia & 8 & 6 & 3 & 127 \\
\hline 14 & Tunisia & 1 & 17 & 3 & 51 \\
\hline 15 & Turkey & 6 & 33 & 3 & 346 \\
\hline 16 & UAE & 10 & 19 & 3 & 63 \\
\hline
\end{tabular}

